\title{
Russian and International Projects in the Field of the Indigenous Peoples' Decorative and Applied Art Development
}

\author{
Natalia M. Libakova* \\ and Ekaterina A. Sertakova \\ Siberian Federal University \\ 79 Svobodny, Krasnoyarsk, 660041, Russia
}

Received 01.07.2017, received in revised form 03.10.2017, accepted 11.10.2017

\begin{abstract}
Modern realities contribute to close intercultural interaction and determine its intensity, which, on the one hand, is a positive factor, facilitating a more effective solution of global problems the mankind faces, but, on the other hand, causes the dissolution of the identity of the indigenous peoples' traditional cultures. Nowadays preservation and development of the decorative and applied art traditions are one of the most successful mechanisms of a positive sign of the uniqueness of culture in the context of multiculturalism. They promote a positive ethnic identity formation, which is particularly important for the indigenous peoples.

The article analyses Russian and international projects aimed at the development of the indigenous peoples' decorative and applied art. It reveals a number of areas in which the projects are implemented: preservation of existing collections of the decorative and applied art memorials, preservation of the traditional skills of creating the decorative and applied art works, training new generations these skills, understanding of the possibilities to integrate traditions and innovations in practice of the decorative and applied art works creation, understanding of value of a traditional decorative and applied art for a modern human, and, finally, arrangement of the events (festivals, fairs) revealing actual meanings of the decorative and applied art works, that, in its turn, generalizes the measures mentioned above.
\end{abstract}

Keywords: decorative and applied art, indigenous peoples, indigenous peoples of the North, ethnic museums, festival, ethnic tourism.

The reported study was funded by the Krasnoyarsk Krai Science and Technology Support Fund. The research project "Decorative and Applied Art of the Indigenous Peoples of the Krasnoyarsk Territory: Current Status, Prospects for Development".

The reported study was funded by the Russian Foundation for Basic Research, Government of Krasnoyarsk Krai, Krasnoyarsk Region Science and Technology Support Fund. The research project № 17-16-24601.

DOI: $10.17516 / 1997-1370-0151$.

Research area: culturology.

(C) Siberian Federal University. All rights reserved

* Corresponding author E-mail address: trognonulia@gmail.com 


\section{Introduction}

In the course of the last decade the international community increasingly turns their attention to such concepts as cultural memory, cultural heritage, traditional culture, etc., realizing not only a need to preserve everything connected with them, but a need to revive and develop them. The largest conferences of UNESCO and ICOM were repeatedly held to discuss the problems existing in this area and mutually find their solutions. As noted in the reports at the conferences, cultural heritage is necessary for modern people since it reflects the knowledge, beliefs and customs of communities, peoples and nations while causing a sense of continuity and identity, favouring the respect for cultural diversity, and forming humanistic values.

Cultures are numerous, they are unique and original. They represent themselves in time and space, asserting their immortality. However, there is another side - every culture feels a need for a figurative "mirror" to fix the identity which is urgently needed. It is the "heritage" that is this "mirror" (Zamiatin, 2008).

In fact, heritage can be considered as a specific mediative mental-and-material layer of culture, which is necessary for its existence and further development. At the same time heritage requires culture, as culture changes its image. Culture must control itself, trace its development. Heritage helps to do it, being an effective monitoring tool. Images of heritage give an idea of culture development outside, thus making it possible to study it in the environment.

Heritage can be understood in two ways: as an area potentially focused on introduction of the new and as a critical historic time. Historic time in this case implies an attempt to strengthen the image of the heritage as "the ancestors' will". This craving is often ideological, detached; it is enhanced at the time of political, social and cultural transformations. Any emerging tradition should be supported ideologically; such a support can be seen in the idea of heritage. A range of questions about heritage can attract attention at the crisis moments of history, when there is a threat to cultural identity, survival of culture itself.

Heritage is an image performing the following functions:

- protection of culture from dying;

- ideological reinforcement of culture, creation of new traditions;

- connecting of different cultures, especially those that are historically or geographically separated.

Heritage needs cultural memory, which relies on its own mechanisms of reproduction (sacred or mundane). Cultural memory is highly selective. It is guided by the principles of appropriateness: culture needs fixing and extension of what is phenomenologically consistent with its distinctive characteristics and gives it a holistic and complete image.

Heritage emerges in culture only when it is necessary to preserve the distinguished past in order to put cultural memory in order and shape, having cleared it from everything nonessential and unimportant; it also construes mental plans in evaluation of cultural values and artifacts.

It is possible to reveal interaction of cultural memory and heritage (even if it is subtle at first glance) in the phenomenon of passeism ${ }^{1}$, which is accompanied by a process of "national/ ethnic Renaissance", return to traditional roots, development of traditionalism in art. In the age of modernization and total change, a significant part of society needs a sustainable cultural platform on the "good old past".

Ethnic revival actualizes cultural heritage, and this in turn leads to the development of spatial interpretations of the image of heritage. This image is associated with the autochthonous cultural landscape, the native land for its peoples. 
At the moment when the image of heritage starts showing its close relationship with the territory and regional identity, the issues of cultural and natural heritage start receiving a more outlined view in the monuments, reflecting the properties of this cultural landscape.

Identity of the community, living in the area, is associated with cultural symbols and artifacts the heritage of which has been recognized. The loss of these monuments is very often compensated due to their great influence and great demand for them.

Thus, substantive interpretation of heritage and its image suggests that it may be a driving force in certain territories (cities, regions, countries) in the economic, political, social and cultural aspects. It may also contribute to the establishment of cultural, social and other institutions in society while becoming an element of prestige of certain groups that make use of heritage.

These processes got intensified in the last quarter of the XX century. It is noticeable in many countries, but especially in small areas where ethnic groups (but not nations) reside.

In a multicultural world, experiencing a strong process of globalization, the traditional culture of the indigenous peoples, whose legacy is most peculiar, is of special interest (Paterson, Karjala, 2003). For them, culture (customs, beliefs, knowledge, artifacts) is largely reflected in art, specifically in the decorative and applied art. According to the Russian scientists N.P. Koptseva and A.O. Karlova (2017), the works of decorative and applied art do not only contain information about peculiar features of a certain indigenous people, but also serve as an effective mechanism for the ethnic identity formation.

Revival of peoples' traditional culture is an important resource in the country's socioeconomic and political development. Enhancing the role of traditional culture reduces the inter- ethnic tension (Koptseva, Pimenova, Seredkina, 2013), strengthens the nation, and provides conditions for the regions' development at the expense of domestic tourism. Decorative and applied arts can be a factor in the regulation of tension between ethnic groups, thus forming positive ideals and values. According to P.E. Bolin, D. Blandy (2003) and M. Kelly (2015), the works of decorative and applied art can act as intermediaries in communication of a person and culture. These views are supported by V.A. Razumovskaia (2016), N.N. Seredkina (2014), A.N. Khizhniakova, K.V. Reznikova (2017), M.E. Shmalts (2017) in their works on communicative practices and the role of images/ concepts in them.

Actualization of traditional culture is actively supported from the top in many states. For example, in the Russian Federation, in the programme article and in his speeches the President V.V. Putin (2006) repeatedly stressed the importance of traditional culture. The programme for the cultural heritage preservation and the traditional culture revival was among the priorities of the state policy in general and of the policies of certain regions in particular (Kargin, Kostina, 2008).

The state support is obviously very important for preservation, promotion and development of the indigenous peoples' decorative and applied art. Yet, support by regional authorities and civil initiative is also important. The latter very often manifests itself in project activities. Many researchers, for example, G.V. Ganshina, N.V. Chaus (2012), F.C. Fussell (2017) note that a variety of projects on traditional culture, crafts and decorative and applied art actualization attract additional resources to the regions, develop partnership between public agencies and the public, serve as an effective management model in the field of regional culture to implement the principles of innovations. 


\section{Problem Statement}

Distinctive features of regional cultural traditions largely depend on geography and economy of the territory and specifics of its population.

The socio-historical experience of the society is reflected in the region's culture and art, especially in folk crafts. Development of decorative and applied art is directly connected with the territory. It reflects the specifics of the surrounding world, captures the forms of a human's interaction with nature. In their folk art ethnic groups use mainly natural materials that are common for the region's raw material resources. These materials are mainly various kinds of clay, various types of stone, bark, wood, bones, etc. All crafts are found in all the regions of the world and Russia. Some of the regions have fairly well-known centres of high-volume production and numerous skilled masters and their apprentices.

If decorative and applied things were earlier created for personal use or a limited circle of people, modern handicrafts have reached the level of production, allowing the people to exist in the post-industrial world. However, it is impossible to maintain a high level of skill (and craft in general) everywhere.

Regarding today's Russia, there is a visual map of crafts. In 2010-2012 the staff of the Center for the study of folk arts and crafts in the Russian State University of Tourism and Service made a large-scale research of the national arts and crafts of Russia, evaluating their current status in different regions of the state (Ganshina, Chaus, 2014). The researchers found out that arts and craft are developing very unevenly in different regions and there are the areas where they are not developing in principle.

In the Siberian federal district, for example (Fig.1), handicraft centres are concentrated mostly in the southern regions. Yet, they are sporadically represented in the territories of compact residence of the indigenous minorities of the North. They do not demonstrate any dynamics in their development or require substantial support. Thriving creative centres were not found in the course of the research.

The situation with a few centres aggravates the quality of mastery of the decorative and applied art products. Some researchers state a loss of native traditions in creation of objects of the decorative and applied art and orientation of the northern ethnic groups' representatives towards mass production. Thus, souvenirs, imitating the decorative and applied art products, replace real works, reflecting the people's cultural perceptions of the world.

These problems noted in Siberia in general and in the north of Krasnoyarsk krai in particular can be solved through the project activity as there is an urgent need to develop programmes and projects, providing an alternative for the situation

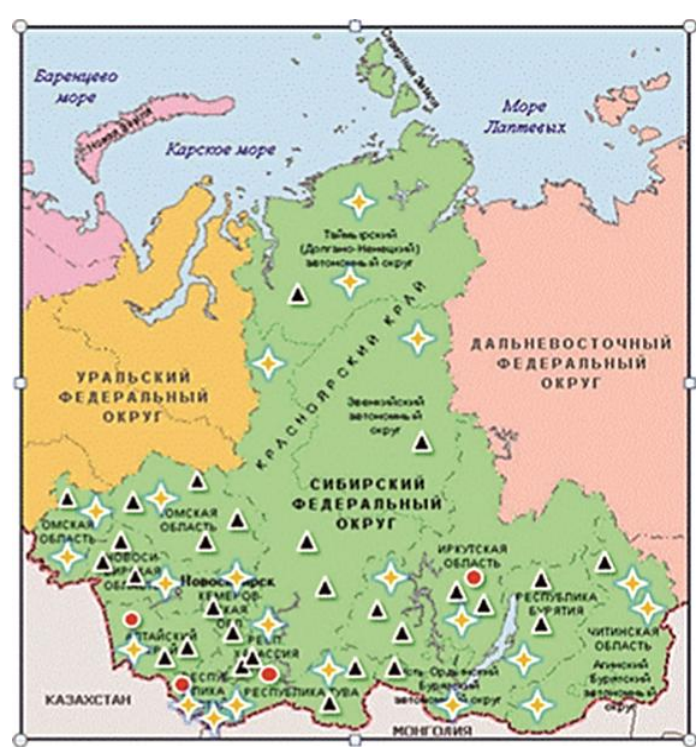

Fig. 1. Folk crafts in Siberian Federal district (based on the materials of the Russian State University of Tourism and Service). Dying (погибающие) crafts a red circle; crafts requiring support - a yellow star; thriving crafts - a green star; crafts functioning without much dynamics in their development - a black triangle 
faced, specifically due to the fact that both in Russia and abroad there is sufficient experience which should and must be addressed.

\section{Methods and Materials}

This study bases on P.L. Berger and T. Luckmann's key provisions on the concept of the social construction of reality (Berger, Luckmann, 1966) which reveals the mechanisms of an individual's adjustment in society, institutionalization of the motives of an individual's behavior, formation of shared meanings in their interiorization. C. Geertz's and V. Turner's provisions on interpretive anthropology (Geertz, 1973; Turner, 1967) are also taken into account. They have become the basis for the research approach that makes it possible to examine the role of symbols of a society's life. Basing on these approaches, it is possible to consider the decorative and applied arts as one of the important elements of social reality which is necessary to construe and translate the ideas, expressing a people's identity.

This study analyzes the existing practices and projects aimed at the indigenous peoples' decorative and applied art preservation and development. Special attention is paid to the peoples living on the territory of the Evenk and Taimyr municipal districts of the Krasnoyarsk Krai.

In addition to the data obtained during the analysis of Russian and international projects in the field of decorative and applied art the study also bases on actual data collected during a complex field research on the territory of the Evenks' residence, the research being carried out from 2010 to the present by the researchers and students of the Department of Culturology of the Siberian Federal University together with the researchers of the Krasnoyarsk State Agricultural University and the Krasnoyarsk State Pedagogical University named after V.P. Astafiev.

\section{Discussion}

Decorative and applied art has a special value for every indigenous people's traditional culture. It is a means to preserve ethnic identity among the representatives of a certain people. This is especially urgent in modern conditions of globalization and close cultural interaction, often leading to dissolution of national identity. In this situation indigenous peoples, suffering from an active influence of the so-called "big cultures", are undoubtedly in the most difficult position (Berry, Dasen et al., 2007).

In this regard, the actual problems are those of preservation of traditional cultures, development of practices inherent in the traditional cultures (for example, decorative and applied art). In the course of the discussion of prospects of the decorative and applied art development the experts focus on different facets of a correspondence of traditions and modernity. The dialectic of traditional and modern is evident on all levels: in the process of training the skills of creating works of the decorative and applied art, in the process of works creation (materials, techniques and technologies, plots), and in the process of a recipient's perception of works of the decorative and applied art, in understanding the value of traditional works for a modern man.

So, one of the discussed issues today is training the skill of creating the works of the decorative and applied art, transfer of skills and mastery. This is evidently of great importance for preservation and development of any type of decorative and applied art. In this regard, various projects are developed for the educational activities to be successfully carried out.

So, Akbar Khakimov, Vice-President of the Academy of Arts of Uzbekistan (Khakimov, 2008), analyzes the current state of affairs in education in the field of art in Uzbekistan, the sphere of the decorative and applied art including. Woodcarvings, embroidery, carpet-weaving are 
types of traditional Uzbek decorative and applied art. The author notes that currently there are three ways of training the skills of the traditional decorative and applied art in Uzbekistan. The first one is training children by older relatives, family traditions translation. The second one is being taught privately by a master. And the third one is academic. It is training in lyceums, colleges, and institutes.

In addition to direct training, experience is also of great value. Atsushi Endo, Noriyuki Kida1, Yutaro Shimode, Isao Oda, Yuka Takai, Akihiko Goto and Hiroyuki Hamada (2015), researchers at Kyoto Institute of Technology, refer to that of urushi, urushi being a Japanese art of lacquering resin of the urushi lacquer tree with its incredible strength, heat resistance, and water resistance. Basing on the analysis of the restoration activity of the experienced masters and the craftsmen with the experience of at least 5 years, the researchers emphasize the importance of experience the masters got in traditional schools. The preparatory stage, during which an urushi master must define the characteristics of works (for example, the amount of metal powder used in the makie technique) with the naked eye, is in the centre of interest.

Woodcarving is a form of traditional decorative and applied art of Malaysia. Basing on the analysis of woodcarving motives common in Terengganu, a federal state of Malaysia, S. Silah, R.O. Basaree, B. Isa, R.S. Redzuan, and Z. Zakaria (2016) suggest the project on modernization of modern training of a new generation of woodcarving masters. The educational project is aimed to contribute to understanding of the essence of the motifs and plots in young masters' works in the context of awareness of philosophical content and aesthetic values of the traditions. This will make it impossible to dissolve in the processes of global modernization.
The value of traditional works of the decorative and applied art for the contemporaries in the context of rapidly changing conditions, determining life style, is important. V.N. Huynh, H. Yan, M. Ryoke, and Y. Nakamori (2011, December) point out that artistic quality and aesthetics are determining factors in evaluation of traditional works (in the sense of recognizing them as important and meaningful), and psychological feelings that arise in the course of a piece of work perception are essential and necessary for the recognition of its value.

The attitude to decorative and applied art was studied by S. Kokko and P. Dillon (2011). Their research project was based on the data obtained in the course of analysis of essays written by 15 students of different nationalities who studied traditional crafts in the framework of the International Study Programme in Finland. Of course, the girls' experience should not be extrapolated to all residents of their native countries or be regarded as translation of some official position. Yet, nevertheless, it resulted in some important conclusions the authors made: personal feelings and collective values are highly dependent on a personal history; in turn, personal histories determine the perception and awareness of values of their crafts as well as attitude to the process of apprenticeship; young people strongly emphasize an aesthetic component in their products, but they do not deny some kind of their economic potential, consider the opportunities of making money by selling the works they have created by their own hands.

The creation of traditional works of the decorative and applied art may also be a promising career. A. Ratnam (2011) noted that all the achievements of modern world do not lead to the loss of value and significance of the products of traditional crafts on the modern market. The author also emphasizes that traditional activities, including the creation of works of the decorative 
and applied art, have prospects for sustainable and comprehensive development as it combines cultural diversity and job satisfaction with creation of beauty, health and usefulness for the consumers. Overall, it can make the modern world more humane and democratic.

Development of the decorative and applied art is supposed to be dynamic due to introduction of new technologies and adaptation of traditional practices to modern conditions. National Taiwan Craft Research and Development Institute (NTCRI) and Taiwan Design Center (TDC) seek to combine traditional methods, craftsmanship and modern design conceptions. Basing on the analysis of works by the winners of the Taiwan Crafts Competition Award and Modern Crafts Yii Project, P.H. Lin, M.L. Yeh, and R. Lin (2013, July) describe a positive experience this project had. The authors note a positive role of national competitions in the decorative and applied art development as this is 1) a platform for interaction between artists, scientists, governments aimed at the development of education in the field of applied art, as well as of regions in general; 2) a means of formation of the younger generation's interest and positive attitudes towards the traditional forms of the decorative and applied art; 3) a means of international branding and successful positioning of the applied art.

The most successful projects on the decorative and applied art development seem to be ones with a method of adaptation of traditional practices of creating works and modern technologies.

For example, modern possibilities of technology are possible in training the masters. D. Smith and R. Kochhar (2008) suggest a project on fixing the "silent content" of the process of casting the products from brass, the project being the Dhokra skill (it is widely-spread in Bina village near Bankur in West Bengal, India). The developed multimedia recording of a casting process makes it possible for the people, willing to learn the craft, to get an adequate understanding of the professional work mediated by the master. The value of multimedia systems productivity, which is in using a full range of registration (video, sound, images of a conventional text and technical schemes), do not diminish the significance of a direct interaction of work with a master teacher. Yet, nevertheless, it gives an opportunity to present very complicated information in various formats. Besides an educational aspect, the project also involves an actual process of production proper, which is in the introduction of modern technology and namely the use of modern furnaces.

A successful project in which modern technologies serve the development of the decorative and applied art is described by Y.F. Chen, P.C. Chan, K.H. Huang, and H.H. Lin (2006). The authors present a digital library, which contains Taiwan traditional artifacts and traditional activities. A feature of this digital library is that it does not only contain artifacts but facilitates interaction with artifacts, skills of artifacts creation and interaction with them. Thus, the collected materials are not only stored in a digital form but also work as resources of online education.

Thus, we can conclude that modern technologies do not deny the traditional forms of activity and the forms of the decorative and applied art in particular. Conversely, they contribute to their preservation and development.

Various forms of ethnic tourism and cultural tourism can be regarded as the most common projects this or that way contributing to the development of the native peoples' decorative and applied art. In general, these types of tourism contribute to the indigenous peoples' traditional cultures maintenance, draw attention to their uniqueness. This gives an opportunity to resist the trends of globalization. The events and activities, 
which make it possible to get acquainted with the peculiarities of a particular culture, become attractors for the tourists (Stoikova, 2015).

One of the brightest events is the "Ethnomir" ("Ethnic World") international project the purpose of which is to promote the dialogue between different ethnic groups by exploring culture and traditions of each other. "Ethnomir" is the largest Russian ethnographic park-museum, which regularly hosts the events during which peoples from different continents demonstrate the uniqueness of their cultures, including works of the decorative and applied art. A peculiar feature of this project is interactivity. The visitors can try their hand at any craft and create their own piece of work. The park-museum locates ethnic podvoryes (Russian storehouses with inns). These are locations displaying artifacts and activities of a certain culture. The visitors can also explore the traditional dwellings of different peoples. They visit izbas (peasants' houses), mud huts, yurts, raw-hide tents, Nepalese and Himalayan houses, and Indian palaces.

ItisworthwhilereferringtoRussiansuccessful projects connected with the development of the indigenous peoples' arts and crafts in details. Among them there are educational, creative and tourism projects. The first and the second types aim at a deeper meaningful acquaintance with an issue of interest. The third one implements an entertaining function to a greater extent but it attracts the largest number of people and is the most popular. These types of projects very often overlap with each other in a separately organized park-museum or event.

The successful ethno-cultural projects related to the development of the indigenous peoples' artistic crafts and handcrafts are described below.

In Russia there are educational projects related to the decorative and applied art. The researchers R. LaMore and M. Root-Bernstein
(2013), V.P. Glăveanu （2013), A. Pryor, P. Bowman (2016) believe that folk crafts form a successful personality and affect his/ her prosperous economic development. A wellknown research at Michigan State University in 1990-1995 showed that involvement in folk crafts rather seriously affected the engineering students. They had more skills and were more creative and innovative in addressing the challenges they faced.

Russian educational projects are related to the activity of universities, colleges, schools or private studios. The researcher I.L. Nabok (2015) notes that the decorative and applied art is one of the strongest exponents of the traditional culture syncretism, it embraces a material side of a human's life, his/her spirituality and sociality. Therefore, the educational programmes at Herzen State Pedagogical University of Russia include the study of the production technologies of the decorative and applied art of the indigenous peoples of the Russian North. Young people are imparted the Northern ethnic groups' theoretical knowledge and practical skills through a skill of working with the material.

Educational projects related to the decorative and applied art today are very important since, firstly, they are connected with the study of an ethnic group's aesthetic foundations, penetration into an ethnic group's history and certain perception of the world, and, secondly, they are directed to the connection of these traditions with innovations, adaptation of ancient hackwork traditions of certain ethnic groups to the conditions of modern multicultural world. The students come up with the projects and develop them themselves that would fulfill the task of preservation and development of cultural heritage of the indigenous peoples of the North.

Educational technologies quite successfully cope with the problems existing in the field of the indigenous peoples' decorative and applied art. 
They not only restore a certain status of folk art in theory but make it possible to transfer knowledge and skills in the field of the decorative and applied art to younger generations in practice, from the masters of a specific skill. They also contribute to creating of something new in creative work as passion for handicrafts perfectly develops creative thinking (Cooke, 2015).

Tourism projects. Ethno-parks or reserve museums are very popular in Russia. Ethnotouristic routes with much emphasis on the indigenous peoples' life and culture are also of a great interest. For example, in Nizhnevartovsk region a route related to the Agansk ethnographic museum-theatre has been successful for several years. Its visitors can see different objects of the Khanty people's life: traditional housing, clothing, decorative household items, and shamanic paraphernalia. The theater visitors can hear the songs of the indigenous peoples of the North and see the best folklore samples.

In the village of Korliki there is a workshopmuseum where the crafts of the Khanty people are preserved and reproduced. The masters work there using old drawings to create clothes and items according to authentic technologies. One can visit the camping ground and learn the skill of the decorative and applied art. The museum staff put their trust in the tourists' interest to the ethnic groups' authentic life, traditions, rituals, creativity, realizing that a citizen's modern, unified life provokes him/her to search for something unique and natural, for his/her identification. Familiarity with ethnic cultures gives this chance to him/her.

In Perm region a series of one-day tourist routes "There is something different in each village" has been successfully running for more than a decade. The residents and visitors get acquainted with a living culture of the indigenous peoples of the Kama region. The aim of the project is to make the territory's ethnic and cultural uniqueness an object of tourism, to show the "other" life that is different from a modern city's life.

The places popular in Siberia are the following ones: the museums of the Khanty people's culture revival "Torum Maa" and "Roda Vella", the museum park "Langepas" in Tyumen region; the Siberian cultural centre of Russian traditional culture in Omsk region; the museumreserve "Tomsk Pisanitsa" in Kemerovo region; The museum "Taltsy" in Irkutsk region. They specialize in actualization of cultural heritage of the indigenous peoples of Siberia. As museums in the open area with quite vast areas, they provide the visitors with a wide range of services, each service being focused on a human's discovery of something still unknown for him/her: some skill or a trait of character. Museum technologies initiate such changes.

Event tourism (ethnic festivals and holidays) has been actively developing. In Russia they are quite a lot. Yet, only a few of them are successful. Most festivals usually attract about 300-500 people who are mostly the region's residents. But there are good exceptions attracting thousands of visitors from different countries and regions. The purpose of these festivals is folk arts and crafts promotion throughout the territory of the Russian Federation, convergence of cultural traditions of the indigenous peoples of Russia.

The largest festivals are:

The "Mnogotsvetie Rossii" ("The Multihued Colours of Russia") festival of national cultures in Moscow. The initiator of this event is the Moscow House of Nationalities. It attracts not only folk masters presenting their creative work at the exhibitions and giving master classes but also ethnic teachers and experts on folk culture who give public lectures (sometimes directly in the exhibition space).

The "Molodye darovaniia" ("Young talents") exhibition-show, annually held in a 
new city of Russia, is sponsored by the "Folk Arts and Crafts" Association. It mainly exhibits the works by students and graduates of the country's specialized educational institutions: the Palekh Art School named after M. Gorky, the Abramtsevo Art and Industrial College named after V.M. Vasnetsov, the Pavlovsk Technical School of Folk Art Crafts of Russia, etc. The main purpose of the event is to show the intergenerational continuity, to emphasize how young craftsmen cherish the peculiar features of Russian crafts, popularize national traditions, and strengthen international relations through creativity.

A huge number of people visit the "MIR Sibiri" ("The World of Siberia") festival of ethnic music and crafts in Shushenskoe village, Krasnoyarsk Krai. A feature of this project is in simultaneous activity of several creative venues in the course of several days, the venues being a concert hall, a ceremonial site, "the town of masters", "ethno-interactivity", a video venue, etc. This all takes place in the open sky in the midst of the beautiful Siberian landscape. The historical-and-ethnographic museum-reserve "Shushenskoe", the state "Sayano-Shushensky" biosphere reserve, the "Ergaki" nature park, the "Shushensky Bor" ("Shushensky Forest") national park are near the festival venue. The festival integrates traditions and innovations. Besides the town of masters where anyone can always get a master-class on creating the works of the decorative and applied art, there is a venue for actual art projects, demonstrating the inextricable connection of times.

The most successful festival projects are those that combine the search for oneself, discovery of something unknown, drive, something that connects life, science and tourism into a single cluster (Konova, 2014).

On the territory of compact residence of the indigenous peoples of the North in Krasnoyarsk Krai there are also projects related to the decorative and applied art. They are predominantly educational and of an event-andtourist format.

Training the art of the indigenous peoples of the Evenk and Taimyr municipal districts of Krasnoyarsk Krai takes place everywhere. Village schools, museums and clubs provide a wide list of activities related to the decorative and applied art. They give classes in beading, working with the fur of deer, bone carving, making clothes, etc.

The national holidays (The Reindeer Herders' Day, the day of winter celebration "Big Argish", the International Day of the Indigenous Peoples of the World) are annually
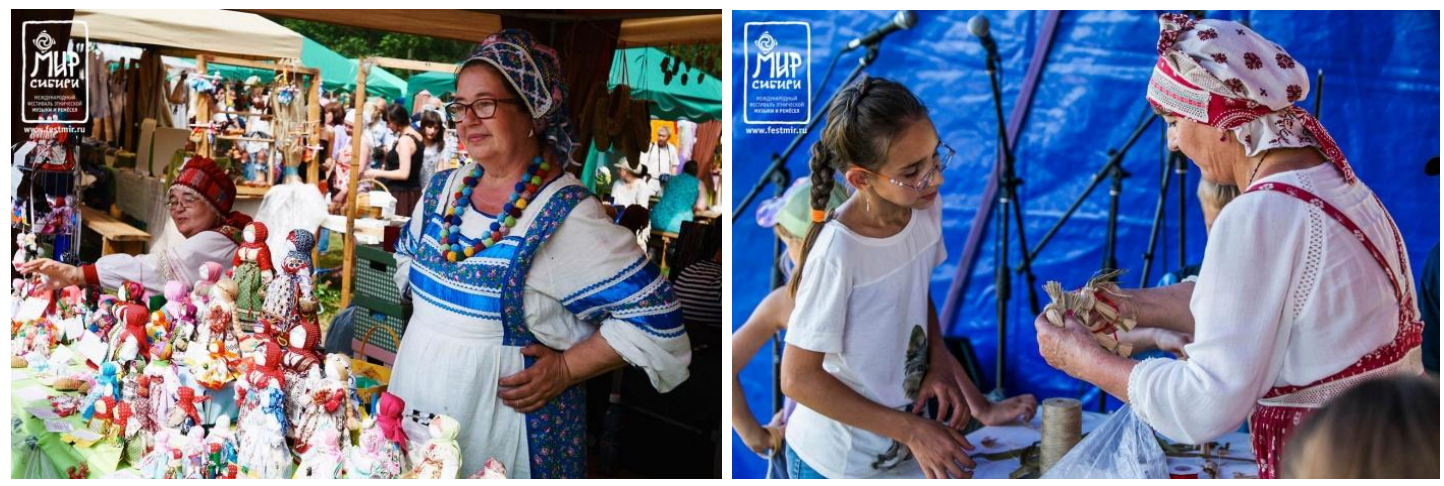

Fig. 2-3. "The Town of Masters". Photos from the official site of the "MIR Sibiri" ("The World of Siberia") festival $^{2}$ 
held in Taimyr and Evenkia. There are also sports events, festivals, merrymaking with the elements of folklore. There is a lot here for ethno-tourism development: the unique natural landscape with a rich resource potential, the human capital, the unique Arctic reindeer herding culture which is preserved almost intact, the culture of hunters and fishermen. The tourist routes could be about learning about the representatives of the indigenous ethnic groups, their way of life, economy and culture. Accommodation in raw-hide tents or beams, taking part in cooking the national dishes, creating of objects of the decorative and applied art, and making rituals are in a great demand among Russian and foreign tourists. The very training course in creation of works of the decorative and applied art of the indigenous peoples of Krasnoyarsk Krai in such an enterprise as "Mukustur" in the city of Dudinka would have a great success.

Based on the use of the territories' recreational potential and traditional culture (the decorative and applied art), such projects could form a new direction in the settlements' socioeconomic development, raise the indigenous population's standard of living, actualize the use of cultural heritage through the tourism mechanisms.

Unfortunately, it is very difficult to attract a large audience to these events. This is because of the remoteness of the holiday or festival venues and lack of developed infrastructure. Yet, we can say that the projects are definitely implemented on the territories mentioned. However, they are not as popular to completely solve the problems of preservation, development and promotion of traditional crafts and trades.

Thus, the review of projects, which are in demand of the residents and guests of the Russian regions, makes it possible to state the reasons of their success:
1. Traditional trades of the indigenous peoples of Russia are an important component in ethno-tourism development. A huge role is played here by the continuity in transfer of ancient technologies of creating traditional pieces of work. Yet, understanding of artistic expression of the people's unique worldview that determines their mentality is of special importance.

2. Despite the potential there are problems in the decorative and applied art development in some regions of Russia. The problems require the coordinated actions of the state, tourist associations, ethnic communities, and educational and socio-cultural institutions. Development and implementation of projects should take into consideration the common conceptual approaches to the region's development. Attracting a large number of the unique cultural heritage lovers, tourism projects can be very promising.

3. The event projects focusing on communication of a human with a living culture are most popular. The exhibits of ethnographical museums have been always interesting for the visitors. Yet, a person's emotions and feelings are genuine and vivid when he/she is directly confronted with them in a natural geographical environment. These are the opportunities to touch, talk, and live a different life that the tourists expect nowadays when choosing the activity format in getting acquainted with the decorative and applied art.

\section{Conclusion}

The indigenous peoples' decorative and applied art is obviously a value. The people all over the world are interested in its preservation and development. In connection with the increasing importance of the Arctic territories of various countries a special attention is paid to the issue of preservation of the traditional natural resources use and vital activities of the indigenous peoples of the North. These peoples are the 
Canadian Inuit people; the Eskimos, the Aleuts and the Iñupiats of Alaska; the Inuit people of Greenland; the Saami people of Norway, Russia and Sweden; the Russian Chukchi, and Russian indigenous peoples living on the territory of Krasnoyarsk Krai (the Evenki people, the Enets, the Nenets, the Nganasans, the Selkups, the Keto, the Dolgans). Overall, the problems related to the support of the indigenous peoples' unique culture and, in particular, preservation and development of the decorative and applied art are currently focused on.

There can be singled out several key areas of work in the field of the decorative and applied art among the existing practices. Firstly, works of the decorative and applied art are preserved in the museums of various levels: school museums on the territories of the indigenous peoples' compact residence (for example, in Surinda village, the Evenki municipal district), museums of local lore (the Evenki museum of local lore in Tura village, the Taimyr museum of local lore in the city of Dudinka), as well as a part of the exhibit collections of ethnographic museums (the Russian Museum of Ethnography and the Kunstkamera in St. Petersburg), history museums (the Canadian Museum of Civilization in Gatineau), art museums (the Surikov Art Museum in Krasnoyarsk), etc.

Secondly, the work on preservation of the tradition in practice of creating works of the decorative and applied art is underway. For example, the House of Children's Creativity in Tura village and the Baikit Centre for Children's Creativity offer the programs for training the skills in beading, working with fur and animal skins in the traditions of the Evenki culture. The "Applied and Decorative Art and Traditional Crafts" educational programme has been implemented in Dudinka, Taymyr College being the basis venue for the programme.
Thirdly, creation of the decorative and applied art works is becoming a focus of business activity (for example, "Mukustur" enterprise Dudinka). On the one hand, this contributes to preservation of the traditional practice of creating the works of the decorative and applied art. On the other hand, introduction of a commercial component to a certain extent leads to emasculation of sacred meanings inherent in the objects of traditional culture. Made as the objects of purchase and sale, the works of the decorative and applied art often represent either utilitarian things: clothes, shoes, dishes, key rings, ashtrays, phone cases, cases for glasses, etc., or decorative ones: all kinds of souvenir items, small indoor sculptures (for example, images of animals, carved from bones, magnets, decorations, etc.).

Analysis of existing international and Russian projects has resulted in giving considerable prominence to a number of relevant tasks the solution of which is a key to successful development of the indigenous peoples' applied and decorative art.

There is a need to systematize the practices of training the skills of creating works of the decorative and applied art, introduce new ways of training, and use the potential of multimedia resources and online learning.

Positioning of the decorative and applied art as a significant form of creative activity to preserve the indigenous peoples' culture is a fundamental issue.

A work of the decorative and applied art integrates aesthetic and utilitarian value. Currently, creation of works of the decorative and applied art is often a matter of business. On the one hand, this can be regarded as a positive thing, contributing to the decorative and applied art development. Yet, at the same time it is urgent to search for a balance between business and traditions of culture spirituality which, one 
way or another, are inherent in any work of the decorative and applied art.

Opening of ethno-museums and ethno-parks, as well as arranging festivals and fairs are the most successful projects in the field of the indigenous peoples' decorative and applied art development. These events favour the decorative and applied art promotion. Yet, there is a risk of profanation and emasculation of primordial deep sacred meanings that are inherent in works of the decorative and applied art. Age-old spirituality, harmony of beauty and use are often lost in favor of the benefits (whether utilitarian, everyday, commercial, or purely aesthetic (“art for art's sake”)).

Passeism is addiction to the past and indifferent (hostile or distrustful) attitude to the present and future.

2 Available at: festmir.ru

\section{References}

Berger, P.L., Luckmann, T. (1991). The Social Construction of Reality: A Treatise in the Sociology of Knowledge (No. 10). Penguin UK.

Berry, J.V., Dasen, P.R., Purtinga, A.H., Sigal, M.H. (2007). Kross-kul'turnaia psikhologiia. Issledovaniia i primenenie [Cross-Cultural Psychology. Research and Application], In Khar'kov [Kharkov], $560 \mathrm{p}$.

Bolin, P.E., Blandy, D. (2003). Beyond Visual Culture: Seven Statements of Support for Material Culture Studies in Art Education, In Studies in Art Education. A Journal of Issues and Research, 44 (3), 246-263.

Chen, Y.F., Chan, P.C., Huang, K.H., \& Lin, H.H. (2006). A Digital Library for Preservation of Folklore Crafts, Skills, and Rituals and Its Role in Folklore Education, In Digital Libraries: Achievements, Challenges and Opportunities, 32-41.

Cooke, P. (2015). The Resilience of Sustainability, Creativity and Social Justice from the Arts \& Crafts Movement to Modern Day "Eco-Painting”, In The Resilient City, City, Culture and Society, 6 (3), 51-60.

Endo, A., Kida, N., Shimode, Y., Oda, I., Takai, Y., Goto, A., Hamada, H. (2015, August). Study on Method of Observing Maki-e Crafts Work in Urushi Craftspeople, In International Conference on Digital Human Modeling and Applications in Health, Safety, Ergonomics and Risk Management. Springer, Cham. 35-45.

Farsani, N.T., Mortazavi, M., Bahrami, A., Kalantary, R., \& Bizhaem, F.K. (2017). Traditional Crafts: a Tool for Geo-Education in Geotourism, In Geoheritage, 1-8.

Federal'naia tselevaia programma "Kul'tura Rossii (2012-2018 gody)": utv. rasporiazheniem Pravitel'stva R.F. [The Federal Target Programme "Culture of Russia (2012-2018)”: approved by the Decree of the Government of the Russian Federation], Available at: http://fcpkultura.ru/new. php?id=9.

Fussell, F.C. (2017). Tradition/Innovation: American Masterpieces of Southern Craft \& Traditional Art, In Journal of American Folklore, 130 (515), 123.

Ganshina, G.V. (2012). Integratsiia etnokul'turnykh sobytii v sotsial'noe prostranstvo Rossii [Integration of Ethnocultural Events into the Social Space of Russia], In Sovremennye problemy servisa i turizma [Modern Problems of Service and Tourism], 4, 16-24.

Ganshina, G.V., Chaus, N.V. (2012). Narodnye khudozhestvennye promysly kak sredstvo aktivizatsii sobytiinogo turizma v Rossii [Folk Art Crafts as a Means of Activating Event Tourism in 
Russia], In Sovremennye problemy servisa i turizma [Modern Problems of Service and Tourism], 2, 76-86.

Ganshina, G.V., Chaus, N.V. (2014). Narodnyye khudozhestvennyye promysly v prostranstve Rossii [Folk Art Crafts in the Space of Russia], In Sovremennye problemy servisa i turizma [Modern Problems of Service and Tourism], 1, 89-96.

Geertz, C. (1973). The Interpretation of Cultures. $470 \mathrm{p}$.

Glăveanu, V.P. (2013). Creativity and Folk Art: A Study of Creative Action in Traditional Craft, In Psychology of Aesthetics, Creativity, and the Arts, 7(2), 140-154.

Huynh, V.N., Yan, H., Ryoke, M., \& Nakamori, Y. (2011, December). Fuzzy Target-Based MultiFeature Evaluation of Traditional Craft Products, In KSEM, 331-342.

Kargin, A.S. Kostina, A.V. (2008). Sokhranenie nematerial'nogo kul'turnogo naslediia narodov RF kak prioritet kul'turnoi politiki Rossii v XXI veke [Preservation of the Intangible Cultural Heritage of the Peoples of the Russian Federation as a Priority of Russia's Cultural Policy in the 21st Century], In Kul'turnaya politika [Cultural Policy], 3, 59-71.

Kelly, M. (2015). Visual Communication Design as a Form of Public Pedagogy, In Australian Journal of Adult Learning, 55 (3), 390.

Khakimov, A. (2008). Art Education in Uzbekistan, In Educating in the Arts, 179-189.

Kokko, S., Dillon, P. (2011). Crafts and Craft Education as Expressions of Cultural Heritage: Individual Experiences and Collective Values Among an International Group of Women University Students, In International Journal of Technology and Design Education, 21 (4), 487-503.

Konova, S.V. (2014). Innovatsionnye podkhody k organizatsii kul'turno-dosugovoi deiatel'nosti v oblasti dekorativno-prikladnogo iskusstva [Innovative Approaches to the Organization of Cultural and Recreational Activities in the Field of Arts and Crafts], In Put' nauki [The path of Science], 7. Available at: https://elibrary.ru/download/elibrary_21946070_92615487.pdf

Koptseva, N.P., Karlova, O.A. (2017). The Formation of Siberian Sub-Ethnic Identity in PostSoviet Russia. In 4th International Multidisciplinary Scientific Conference on Social Sciences \& Arts SGEM 2017. Science and Arts. 165-170.

Koptseva, N.P., Khizhniakova, A.N., Reznikova, K.V. (2017). K voprosu o kontseptakh iazykov korennykh narodov Krasnoiarskogo kraia [On the Issue of the Concepts of Indigenous Languages of the Krasnoyarsk Territory], In Severnye arkhivy i ekspeditsii [Northern Archives and Expeditions], 1, 6-22.

Koptseva, N.P., Pimenova, N.N., Seredkina, N.N. (2013). Izuchenie dekorativno-prikladnogo iskusstva i traditsionnykh religii korennykh malochislennykh narodov Severa kak faktor formirovaniia pozitivnoi obshcherossiiskoi kul'turnoi identichnosti [Study of Arts and Crafts and Traditional Religions of Indigenous Minorities of the North as a Factor in the Formation of a Positive All-Russian Cultural Identity], In Pedagogika iskusstva [Pedagogy of Art], 2, 15-30. Available at: http://www.arteducation.ru/sites/default/files/journal_pdf/koptseva_pimenova_seredkina_2_2013.pdf.

Korovushkin, D.G. (2017). Boguchanskaia arkheologicheskaia ekspeditsiia IAET SO RAN: kratkii istoricheskii ocherk [Boguchansk Archaeological Expedition of the IAET SB RAS: a Brief Historical Essay], In Severnyye Arkhivy i Ekspeditsii [Northern Archives and Expeditions], 2, 23-42.

LaMore, R., Root-Bernstein, R., Root-Bernstein, M. (2013). Arts and Crafts, In Critical to Economic Innovation, 27 (3), 221-229 
Libakova, N.M., Kolesnik, M.A., Sertakova E.A., Sergeeva N.A. (2017). Issledovatel'skie vozmozhnosti antropologii iskusstva na primere kostoreznykh proizvedenii masterov Sibiri [Research Opportunities Anthropology of Art on the Example Carving Works of the Masters of Siberia], In Sibirskii antropologicheskii zhurnal [Siberian Anthropological Journal], 1 (06), 22-34.

Lin, P.H., Yeh, M.L., Lin, R. (2013, July). A Study of Aesthetic Analysis on Modern Crafts. In International Conference on Cross-Cultural Design. Springer, Berlin, Heidelberg, 118-127.

Nabok, I.L. (2015). Khudozhestvenno-esteticheskie traditsii korennykh malochislennykh narodov Severa v sovremennom kul'turno-obrazovatel'nom prostranstve Rossii [Artistic and Aesthetic Traditions of Indigenous Minorities of the North in the Contemporary Cultural and Educational Space of Russia], In Aktual'nye voprosy gumanitarnykh nauk v sovremennykh usloviiakh razvitiia strany [Actual Issues of the Humanities in the Current Conditions of the Country's Development], 18-20.

Paterson, R.K., Karjala, D.S. (2003). Looking Beyond Intellectual Property in Resolving Protection of the Intangible Cultural Heritage of Indigenous Peoples. Cardozo J. Int'l \& Comp. L,. 633.

Pryor, A., Bowman, P. (2016). Folklore and Education: a Short History of a Long Endeavor, In Journal of American Folklore, 129 (514), 436.

Putin, V.V. (2006). Vystuplenie na zasedanii Gosudarstvennogo soveta "O gosudarstvennoi podderzhke traditsionnoi natsional'noi kul'tury v Rossii” [Speech at a Meeting of the State Council "On State Support of Traditional National Culture in Russia”]. Available at: archive.Kremline.ru/ text/ appears2/2006/12/26/116109.html.

Ratnam, A. (2011). Traditional Occupations in a Modern World: Implications for Career Guidance and Livelihood Planning, In International Journal for Educational and Vocational Guidance, 11 (2), 95-109.

Razumovskaia, V.A. (2016). Kul'turnyi meinstrim khudozhestvennogo perevodovedeniia: skazki narodov sibirskogo Severa v perevodakh [Cultural Mainstream of Literary Translation Studies: Tales of the Peoples of the Siberian North in Translations], In Dinamika iazykovykh i kul'turnykh protsessov $v$ sovremennoi Rossii [Dynamics of Language and Cultural Processes in Modern Russia], 5, 989-993.

Seredkina, N.N. (2014). K voprosu o metodologicheskikh printsipakh kul'turnosemioticheskogo podkhoda v izuchenii iskusstva indigennykh narodov Severa, Sibiri i Dal'nego Vostoka [On the Methodological Principles of the Cultural-Semiotic Approach in Studying the Art of Indigenous Peoples of the North, Siberia and the Far East], In Chelovek i kul'tura [Man and Culture], 2, 127-146.

Shmalts, M.E. (2017). Migratsionnaia travma kak faktor obedneniia iazykov korennykh malochislennykh narodov Sibiri: primer nizhnekolymskikh iukagirov [Migration Trauma as a Factor in the Language Impoverishment of Indigenous Small-Numbered Peoples of Siberia: the Example of the Lower Kolyma Yukaghirs], In Sibirskii antropologicheskii zhurnal [Siberian Anthropological Journal], 1 (06), 43-51.

Silah, S., Basaree, R.O., Isa, B., Redzuan, R.S., Zakaria, Z. (2016). The Structure of Malay Woodcarving Motifs in Craft Education Module. In Proceedings of the 2nd International Colloquium of Art and Design Education Research (i-CADER 2015). Springer, Singapore, 429-439.

Smith, D., Kochhar, R. (2008). Multimedia Archiving of Technological Change in a Traditional Creative Industry: a Case Study of the Dhokra Artisans of Bankura, West Bengal. In Cognition, Communication and Interaction. Springer London, 501-516. 
Stoikova, B. (2015). Authenticity of Ethnic Tourism (Based on the Example of the Congregation of the Karakachans in Bulgaria), In International Review on Public and Nonprofit Marketing, 12 (3), 297-313.

Turner, V.W. (1967). The Forest of Symbols: Aspects of Ndembu Ritual (Vol. 101). Cornell University Press.

Zamaraeva, Y.S., Reznikova, K.V., Pimenova, N.N. (2017). Istoriia antropologicheskikh issledovanii korennykh narodov Sibiri [The History of Anthropological Studies of the Indigenous Peoples of Siberia], In Sibirskii antropologicheskii zhurnal [Siberian Anthropological Journal], 1 (06), 6-21.

Zamiatin, D.N. (2008). Obraz naslediia v kul'ture. Metodologicheskiye podkhody k izucheniiu poniatiya naslediia [An Image of Heritage in Culture. Methodological Approaches to the Study of the Concept of Heritage], In Etnograficheskoe obozrenie [Ethnographic Review], 6, 121-130.

\title{
Российские и международные проекты в области развития декоративно-прикладного искусства коренных народов
}

\author{
Н.М. Либакова, Е.А. Сертакова \\ Сибирский федеральный университет \\ Россия, 660041, Красноярск, пр. Свободный, 79
}

\begin{abstract}
Современные реалии способствуют тесному межкультурному взаимодействию и предопределяют его интенсивность, что, с одной стороны, служит положительным фактором, позволяюшим более эффективно решать глобальные проблемы, касающиеся всего человечества, но, с другой стороны, приводит к растворению самобытности традиционных культур коренных народов. Сохранение и развитие традищий декоративно-прикладного искусства (ДПИ) на сегодняиний день является одним из успешных механизмов позитивного обозначения уникальности культуры в контексте мультикультурализма, а также способствует формированию позитивной этнической идентичности, что особенно важно для коренных малочисленных народов.

В статье представлен анализ российских и международных проектов, цель которых - развитие декоративно-прикладного искусства коренных народов. В ходе их анализа был выявлен ряд направлений, в рамках которых реализуются проекты: сохранение существующих коллекиий памятников ДПИ, сохранение мастерства создания традииионных произведений ДПИ и обучение мастерству новых поколений, осмысление возможностей сочетания традиций и новаций в практике создания произведений ДПИ, осмысление ценности традиционного ДПИ для современного человека, и как обобщающее перечисленных направленностей, - проведение мероприятий (фестивалей, ярмарок), в рамках которых раскрываются актуальные смысльы произведений декоративно-прикладного искусства.
\end{abstract}

Ключевые слова: декоративно-прикладное искусство (ДПИ), коренные народы, коренные малочисленные народы Севера, этномузеи, фестиваль, этнотуризм.

Исследование выполнено при поддержке краевого государственного автономного учреждения «Красноярский краевой фонд поддержки научной и научно-технической деятельности» в рам- 
ках реализаџии проекта: «Декоративно-прикладное искусство коренных малочисленных народов Красноярского края: современное состояние, перспективы развития.

Исследование выполнено при финансовой поддержке Российского фонда фундаментальных исследований, Правительства Красноярского края, Красноярского краевого фонда поддержки научной и научно-технической деятельности в рамках научного проекта № 17-16-24601.

Научная специальность: 24.00.00 - культурология. 